\title{
Peningkatan Kualitas Dan Kuantitas Produksi Melalui Perbaikan Teknologi Produksi Pada UKM Pengrajin Tas
}

\author{
Budihardjo Achmadi Hasyim ${ }^{1}$, Iskandar ${ }^{2}$, Yunus ${ }^{3}$ \\ 1,2,3 Jurusan Teknik Mesin, Universitas Negeri Surabaya \\ ${ }^{1}$ budihardjoachmadi@universitas.ac.id \\ iskandar@unesa.ac.id \\ 3yunus@unesa.ac.id
}

\begin{abstract}
Abstrak-Kegiatan ini bertujuan untuk membantu menyelesaikan rendahnya produktvitas UKM pengrajin tas "ENDXEN" dan tas "SYAFA'AT" di Gresik. Permasalahan urgen yang harus segera diselesaikan dalam upaya meningkatkan produktivitas kedua UKM pengrajin tas ini adalah perbaikan teknologi produksi melalui penerapan teknologi tepat guna (TTG) berupa mesin jahit elektrik untuk menggantikan mesin jahit manual. Metode untuk mengatasi permasalahan tersebut dilakukan melalui penerapan mesin jahit elektrik melalui kegiatan pelatihan dan pendampingan. Berdasarkan hasil kegiatan yang telah dilakukan maka dapat diketahui bahwa pengusaha kecil pengrajin tas ini telah dapat meningkatkan produktivitas produksinya dan karyawan meningkat penghasilannya, yakni untuk jenis tas rangsel laptop dari 7 tas/hari menjadi 14 tas/hari sehingga ada peningkatan produksi $100 \%$ dan upah untuk satu tas rangsel Rp.8.000 sehingga penghasilan karyawan meningkat dari Rp.56.000 menjadi Rp.112.000, dan untuk jenis tas sekolah dari 12 tas per hari menjadi 30 tas per hari, sehingga ada peningkatan produksi $150 \%$ dan upah untuk satu tas sekolah Rp.4.000 sehingga penghasilanya karyawan meningkat dari Rp.48.000 menjadi Rp.120.000.
\end{abstract}

Kata Kunci- teknologi produksi, produktivitas, pengrajin tas.

\begin{abstract}
This activity aims to help resolve the low productivity of SME "ENDXEN" bag craftsmen and "SYAFA'AT" bags in Gresik. An urgent problem that must be resolved immediately in an effort to increase the productivity of the two UKM bag craftsmen is the improvement of production technology through the application of appropriate technology (TTG) in the form of electric sewing machines to replace manual sewing machines. The method to overcome these problems is done through the application of electric sewing machines through training and mentoring activities. Based on the results of the activities carried out, it can be seen that small bag craftsmen entrepreneurs have been able to increase their production productivity and employees have increased their income, namely for laptop bags from 7 bags / day to 14 bags / day so there is a $100 \%$ increase in production and wages for one bag of ragel Rp.8,000 so that the employee's income increased from Rp.56,000 to Rp.112,000, and for the type of school bag from 12 bags per day to 30 bags per day, so there was an increase in production of $150 \%$ and a wage for one school bag Rp.4,000 so that the employee's income increased from Rp.48,000 to Rp.120,000.
\end{abstract}

Keywords - production technology, productivity, bag craftsmen.

\section{PEndahuluan}

Kabupaten Gresik merupakan salah satu wilayah kabupaten di Jawa Timur yang cukup padat industri, baik industri kecil, industri menengah maupun industri besar. Beberapa produk sentra industri kecil yang ada di kabupaten Gresik yang sudah terkenal adalah produk kopyah (songkok), tas, dompet, batik tulis, bordir, busana muslim, dan lain-lain. Namun demikian, masih banyak usaha kecil menengah (UKM) yang produktivitasnya masih rendah dan memiliki potensi sangat bagus untuk dikembangkan. Akan tetapi, kurangnya kepedulian, pengawasan, koordinasi, dan pembinaan/pelatihan, yang dilakukan oleh pemerintah daerah dan/atau dari perguruan tinggi, baik dari aspek teknologi prod uksi maupun aspek manajemen usaha, menyebabkan kualitas dan kuantitas produksinya rendah dan belum berkembang dengan baik. Disamping itu, kurangnya permodalan dan sulitnya menggandeng perbankan dalam mendapatkan kucuran bantuan modal, dirasa menghambat berkembangnya UKM tersebut. Di antara UKM kerajinan tas yang dimaksud adalah UKM pengrajin tas, TAS ENDXEN, di Jl. KH. Abdul Karim, 25/3, Gresik milik Hasanudin, dan TAS SYAFA'AT Jl. Kh. Abdul Karim 23/2 Gresik, milik Muhammad Toyib. Produk tas kedua pengrajin tas ini mempunyai prospek usaha yang bagus bila didukung dengan teknologi tepat guna yang memadai dan dikelola dengan manajemen usaha yang baik. Kurangnya dukungan teknologi produksi dan lemahnya manajemen usaha menyebabkan produktivitas UKM pengrajin tas ini, dilihat dari aspek kualitas maupun kuantitas produk yang dihasilkan masih rendah, daya saing produk juga masih rendah dan kurang diminati oleh konsumen.

Rendahnya produktivitas baik secara kualitas maupun kuantitas produksi merupakan permasalahan urgen yang harus segera diselesaikan dalam upaya meningkatkan dan mengembangkan kedua UKM pengrajin tas ini. Permasalahan yang paling urgen untuk segera diselesaikan dalam upaya meningkatkan produktivitas kedua UKM pengrajin tas ini adalah: (1) permasalahan pada aspek produksi, yakni kurangnya dukungan teknologi produksi tepat guna yang memadai, dimana proses produksi masih menggunakan mesin jahit konvensional yang digerakkan secara manual, dan (2) lemahnya manajemen usaha UKM mitra.

Untuk menyelesaikan permasalahan tersebut, dilakukan melalui penerapan teknologi tepat guna (TTG) berupa mesin jahit elektrik. Dengan adanya penerapan TTG berupa mesin jahit elektrik pada kelompok UKM pengrajin tas, sehingga 
permasalahan UKM tas ini dapat diselesaikan, diharapkan produktivitas UKM pengrajin tas ini dapat meningkat secara signifikan dan UKM ini dapat berkembang menjadi UKM yang maju, tangguh dan mandiri dan untuk jangka panjang produk tas UKM ini diharapkan dapat menembus pasar ekspor yang pada akhirnya berdampak pada peningkatan pendapatan dan kesejahteraan pengusaha dan karyawan.

UKM TAS "ENDXEN" dan UKM TAS "SYAFAAT" ini produk utama yang dihasilkan berupa tas, seperti tas seminar, tas sekolah, tas kerja, tas hajatan, dan lain-lain. Kemudian, dari sisi kebutuhan bahan baku ternyata cukup banyak komponen bahan baku yang dibutuhkan untuk memproduksi satu jenis produk tas yang dihasilkan. Namun demikian, UKM ini tidak mengalami kesulitan di dalam memperoleh dan memenuhi kebutuhan bahan baku dan bahan pendukung yang dibutuhkannya. Untuk kebutuhan bahan baku tas dan lain-lain dapat dipenuhi di kota Gresik dan/atau Surabaya. Tabel 1 berikut adalah contoh kebutuhan bahan baku untuk memproduksi 1 unit tas rangsel/lap top.

Tabel 1. Data Kebutuhan Bahan Baku untuk Memproduksi 1 Unit Tas Rangsel/Lap Top

\begin{tabular}{|c|l|c|c|c|}
\hline No. & \multicolumn{1}{|c|}{$\begin{array}{c}\text { Nama } \\
\text { Bahan }\end{array}$} & $\begin{array}{c}\text { Kuanti } \\
\text { tas }\end{array}$ & $\begin{array}{c}\text { Harga } \\
\text { Satuan }\end{array}$ & $\begin{array}{c}\text { Kuantitas } \\
\text { dalamRp. }\end{array}$ \\
\hline 1. & Kepala & $5 \mathrm{bh}$ & $700,-$ & $3.500,-$ \\
\hline 2. & Rantai besar & $1 \mathrm{rantai}$ & $1.500,-$ & $1.500,-$ \\
\hline 3. & D 300 & $1 \mathrm{Jar}$ & $14.000,-$ & $14.000,-$ \\
\hline 4. & Selang & $1 \mathrm{~m}$ & $2.000,-$ & $2.000,-$ \\
\hline 5. & Cap & $1 \mathrm{bh}$ & $750,-$ & $750,-$ \\
\hline 6. & Busa pop & $1 \mathrm{~m}{ }^{2}$ & $8.000,-$ & $8.000,-$ \\
\hline 7. & Bisban $2,5 \mathrm{~cm}$ & $1 \mathrm{rol}$ & $8.000,-$ & $8.000,-$ \\
\hline 8. & Bisban $28,5 \mathrm{~cm}$ & $1 \mathrm{rol}$ & $10.000,-$ & $10.000,-$ \\
\hline 9. & Slop & $1 \mathrm{bh}$ & $1.000,-$ & $1.000,-$ \\
\hline 10. & Leter bungkuk & $2 \mathrm{bh}$ & $2.000,-$ & $4.000,-$ \\
\hline 11. & Leter 8 & $1 \mathrm{bh}$ & $1.000,-$ & $1.000,-$ \\
\hline 12. & Leter D & $1 \mathrm{bh}$ & $1.000,-$ & $1.000,-$ \\
\hline 13. & Puring & $1 \mathrm{Jar}$ & $6.000,-$ & $6.000,-$ \\
\hline 14. & Karet 0,5 cm & $1 \mathrm{rol}$ & $1.500,-$ & $1.500,-$ \\
\hline 15. & Jaring/krawanga & $1 \mathrm{bh}$ & $2.000,-$ & $2.000,-$ \\
\hline 16. & Benang nilon & $1 \mathrm{bh}$ & $3.000,-$ & $3.000,-$ \\
\hline 17. & Ongkos tukang & 1 unit & $5.000,-$ & $5.000,-$ \\
\hline & & Jumlah & $\mathbf{6 5 . 4 5 0 , -}$ \\
\hline
\end{tabular}

Untuk peralatan produksi, UKM TAS ENDXEN dan UKM TAS SYAFAAT ini masih menggunakan peralatan-peralatan sederhana, antara lain: 1) gunting tangan, 2) cutter, 3) lem perekat, dan 4) mesin jahit manual/kayuh seperti pada Gamar 1. Dengan menggunakan peralatan tersebut, khususnya kualitas jahit dan kuantitas produk tas yang dihasilkan masih rendah dan masih sangat memungkinkan untuk ditingkatkan dan dikembangkan. Ini merupakan permasalahan pada aspek produksi yang harus diatasi untuk meningkatkan kualitas dan kuantitas produksinya. Menurut kedua UKM tersebut, indikator rendahnya kualitas produksi ditandai oleh adanya komplain dari pelanggan yang mengeluhkan kurang kuatnya jahitan, jahitannya kasar (kurang halus), kurang rapi, kadangkala disain dan kreasi gambar, logo, sablon, dan lainnya juga kurang menarik. Sementara itu, rendahnya kuantitas produksi ditandai dengan sering terjadinya keterlambatan dalam memenuhi pesanan dan belum mampu memenuhi pesanan pelanggan sesuai dengan kuantitas dan waktu yang ditentukan.

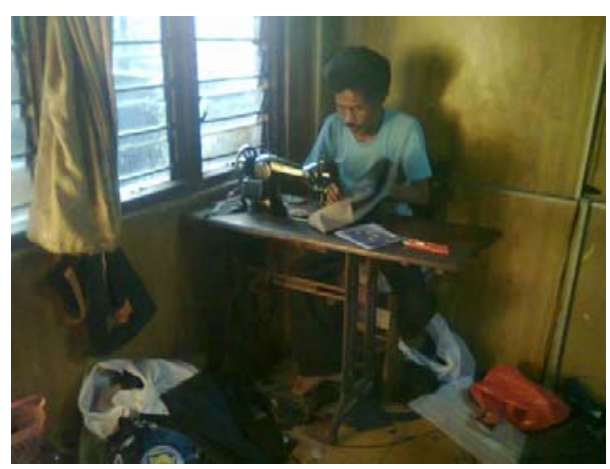

Gambar 1. Karyawan sedang menjahit tas menggunakan mesin jahit kayuh

\section{METODE}

Metode pelaksanaan program IbM dalam rangka menemukan dan menyelesaikan permasalahan pada aspek produksi pada UKM tas mitra tersebut di tas, dilakakukan dengan langkah-langkah sebagai berikut: (1) menemui kedua pengusaha UKM tas yang dijadikan mitra dalam pelaksanaan program IbM, yaitu Hasanudin pengrajin TAS ENDXEN, di Jl. KH. Abdul Karim, 25/3, Gresik, dan Muhammad Toyib pengrajin TAS SYAFA'AT di Jl. Kh. Abdul Karim 23/2 Gresik; (2) menyampaikan maksud dan tujuan pelaksanaan program IbM kepada pengusaha UKM tas mitra; (3) melakukan wawancara dengan pengusaha UKM tas untuk menggali informasi tentang keberhasilan, kegagalan, faktor pendukung dan faktor penghambat serta permasalahan yang dihadapi dalam mengembangkan usahanya; (4) melakukan observasi proses produksi dan pelaksanaan manajemen usaha pada UKM mitra untuk melengkapi data yang diperoleh dari hasil wawancara; (5) menganalisis data hasil wawancara, observasi dan mendiskusikan bersama dengan pengusaha UKM mitra untuk menentukan permasalahan prioritas mitra yang harus segera diselesaikan; (6) dari hasil diskusi dengan pengusaha UKM mitra, dapat diketahui bahwa permasalahan prioritas dari aspek produksi yang harus segera diselesaikan dalam rangka meningkatkan kuantitas dan kualitas produksi tas UKM mitra adalah pada proses produksi tas yang menggunakan mesin jahit manual.

\section{HASIL DAN PEMBAHASAN}

\section{Hasil}

Hasil yang ditargetkan dari pelaksanaan program IbM pada UKM pengrajin TAS ENDXEN dan TAS SYAFAAT ini, adalah: (1) terealisasikannya TTG berupa 4 mesin jahit elektrik untuk kegiatan produksi. Mesin jahit elektrik sudah banyak dikenal oleh para pengusaha pengrajin tas, sepatu, konveksi, dan lain-lain. Mesin jahit elektrik ini sudah banyak dijual di toko-toko mesin jahit dengan berbagai merk, seperti Singer, Yamato, Pegasus, Juki, Toyota, Brother, 
Shunfa, Jack, Kansai, Siruba, Meijia, Sun Star, dan Janome baik produk negara Jepang, China, Taiwan, Jerman, dan lain sebagainya. Upaya penerapan mesin jahit elektrik kepada kedua UKM tas tersebut, dilakukan berdasarkan hasil observasi dan wawancara dengan karyawan pengrajin TAS ENDXEN dan TAS SYAFAAT. Dari wawnacara dapat diketahui bahwa pola pikir para karyawan masih kolot, dimana mereka berpendapat bahwa lebih mudah dan lebih nyaman bekerja dengan mesin jahit manual dari pada mesin jahit elektrik dan mereka tetap yakin bahwa bekerja dengan mesin jahit manual hasilnya lebih baik dan lebih banyak, karena mereka sudah merasa terampil menggunakan mesin jahit manual. Para karyawan juga mengatakan, bahwa mesin jahit elektrik putarannya terlalu cepat dan sangat sulit dikendalikan. Pola pikir para karyawan yang seperti ini menjadi tugas tim pelaksana IbM untuk memberikan pemahaman agar terjadi perubahan pola berpikir yang maju melalui kegiatan pendampingan dan pelatihan. Pola pikir bahwa mesin jahit elektrik terlalu cepat dan sulit dikendalikan merupakan sifat karyawan yang didasari oleh rasa malas untuk belajar. Tetapi tim pelaksana program IbM ini yakin bahwa dengan melatih dan mendampingi mereka untuk mengoperasikan mesin jahit elektrik di luar jam kerja mereka, maksimal dalam waktu 1 bulan, para karyawan akan menyadari bahwa apa yang mereka pikirkan selama ini salah dan akan menyadari bahwa bekerja dengan mesin jahit elektrik lebih mudah, lebih cepat dan hasilnya lebih baik.

Untuk mendukung keterlaksanaan program pelatihan dan pendampingan guna meningkatkan keterampilan dalam mengoperasikan mesin jahit elektrik dan menyadarkan mereka bahwa bekerja dengan mesin jahit elektrik lebih menyenangkan, tidak melelahkan, kualitas hasilnya lebih baik dan jumlah produk yang dihasilkaan lebih banyak, maka diserahkan 4 unit mesin jahit elektrik, dengan rincian 2 unit mesin jahit elektrik diberikan kepada Hasanudin pengrajin TAS ENDXEN dan 2 unit mesin jahit elektrik lainnya diberikan kepada Muhammad Toyib pengrajin TAS SYAFA'AT. Serah terima mesin jahit elektrik kepada pengusaha UKM tas dapat dilihat pada Gambar 2.

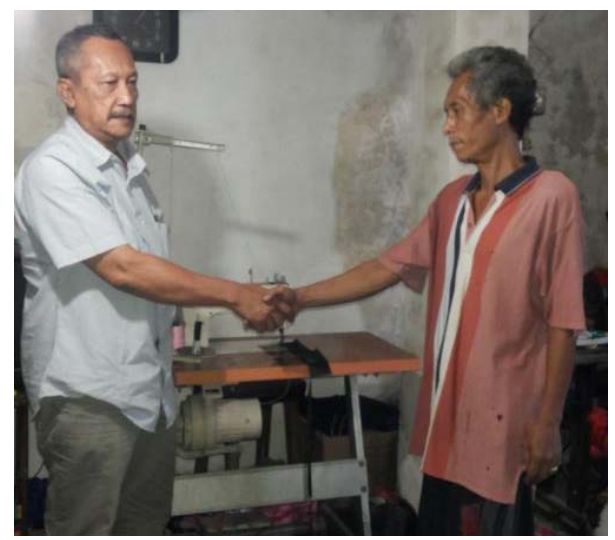

Gambar 2. Serah terima mesin jahit elektrik ke UKM tas
Tahapan selanjutnya yaitu karyawan kedua UKM tas ini diberikan pelatihan dan pendampingan. Diakhir kegiatan kepada karyawan dilakukan tes keterampilan. Kepada karyawan diminta untuk menjahit tas rangsel laptop dengan menggunakan mesin jahit manual dan mesin jahit elektrik. Hasilnya menunjukkan adanya perbedaan yang signifikan pada aspek waktu (kuantitas) dan aspek kualitas. Untuk menyelesaikan 1 tas rangsel laptop dengan mesin jahit manual membutuhkan waktu \pm 60 menit dan dengan menggunakan mesin jahit elektrik membutuhkan waktu 30 menit, berarti ada peningkatan $100 \%$, dan untuk jenis tas sekolah dari 12 tas per hari menjadi 30 tas per hari, sehingga ada peningkatan produksi $150 \%$ dimana tas rangsel dan tas sekolah yang dikerjakan dengan mesin jahit elektrik kualitas hasil lebih baik, yakni jahitannya lebih halus, lebih rapi dan lebih kuat.

\section{Pembahasan}

Berdasarkan pada hasil akhir kegiatan pelatihan dan pendampingan dalam mengoperasikan mesin jahit elektrik tersebut di atas, menunjukkan bahwa mesin jahit elektrik dapat digunakan untuk kegiatan produksi dengan tingkat produktivitas yang tinggi tergantung pada tingkat keterampilan seorang penjahit. Jika dibandingkan dengan mesin jahit manual yang selama ini dilakukan oleh UKM mitra, maka penggunaan mesin jahit elektrik ini memberikan banyak kelebihan/keuntungan, yaitu: (1) produk tas yang dihasilkan lebih baik; (2) lebih efektif dan efisien dari sisi waktu, tenaga, dan biaya, yaitu untuk menjahit satu jenis tas rangsel laptop membutuhkan waktu maksimal 60 menit dengan mesin jahit manual menjadi \pm 30 menit dengan mesin jahit elektrik, menghasilkan tas laptop dari 7 tas menjadi 14 tas, dan untuk jenis tas sekolah dari 12 tas per hari menjadi 30 tas per hari, (3) tenaga yang dibutuhkan ringan, karena tugas karyawan hanya menekan injakan on-off, (4) biaya produksi menjadi lebih murah, karena dengan tenaga dan waktu yang lebih singkat menghasilkan produk tas dengan kualitas yang lebih baik dan kuantitas produksi yang lebih banyak; dan (5) pengusaha UKM pengrajin tas dapat meningkatkan produktivitas produksinya dan karyawan meningkat penghasilannya, yakni untuk jenis tas rangsel laptop membutuhkan waktu maksimal 60 menit dengan mesin jahit manual menjadi \pm 30 menit, menghasilkan tas laptop dari 7 tas menjadi 14 tas perhari sehingga ada peningkatan produksi $100 \%$ dan upah untuk satu tas rangsel Rp. 8.000,penghasilan karyawan meningkat dari Rp.56.000,00 menjadi Rp. 112.000,00, dan untuk jenis tas sekolah dari 12 tas per hari menjadi 30 tas per hari, sehingga ada peningkatan produksi $150 \%$ dan upah untuk satu tas sekolah Rp. 4000,-, sehingga penghasilanya karyawan meningkat dari Rp. 48.000,00 menjadi Rp. 120.000,00. Perbandingan hasil produksi tas dan penghasilan karyawan produksi tas yang dikerjakan dengan mesin manual dan mesin elektrik dapat dilihat pada Tabel 2, dan grafik pada Gambar 3 dan Gambar 4.

Tabel 2. Perbandingan Peningkatan Kuantitas Produksi dan 
Peningkatan Penghasilan Produksi Tas Sekolah dan Tas Rangsel antara yang Dikerjakan dengan Mesin Jahit Manual dan Mesin Jahit Elektrik

\begin{tabular}{|l|ccc|cc|}
\hline \multicolumn{1}{|c|}{ Jenis Tas } & \multicolumn{2}{|c|}{ TasSekolah } & \multicolumn{2}{c|}{ TasRangsel } \\
\hline \multicolumn{1}{|c|}{ Jenis Mesin } & $\begin{array}{c}\text { Mesin Jahit } \\
\text { Manual }\end{array}$ & $\begin{array}{c}\text { Mesin Jahit } \\
\text { Elektrik }\end{array}$ & $\begin{array}{c}\text { Mesin Jahit } \\
\text { Manual }\end{array}$ & $\begin{array}{c}\text { Mesin Jahit } \\
\text { Elektrik }\end{array}$ \\
\hline Kapasitas Produksi (tas/hari) & 12 & 30 & 7 & 14 \\
\hline UpahProduksi (Rp./tas) & 4000 & 4000 & 8000 & 5000 \\
\hline PenghasilanKaryawan (Rp./hari) & 48.000 & 120.000 & 56.000 & 112.000 \\
\hline
\end{tabular}

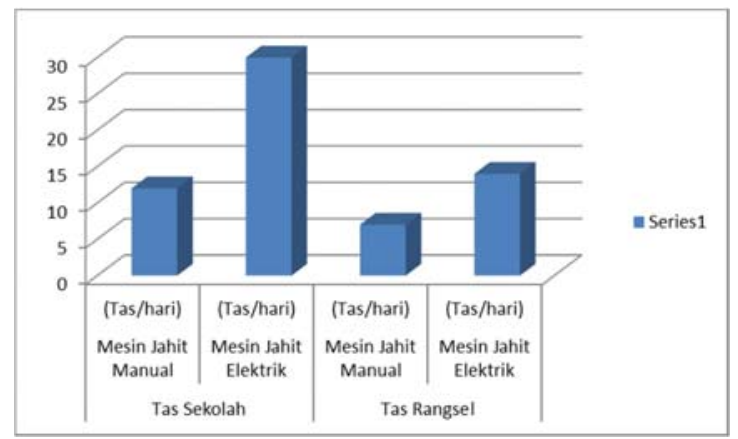

Gambar 3. Grafik Perbandingan Kuantitas Produksi Tas Sekolah dan Tas Rangsel antara yang Dikerjakan dengan Mesin Jahit Manual dan Mesin Jahit Elektrik

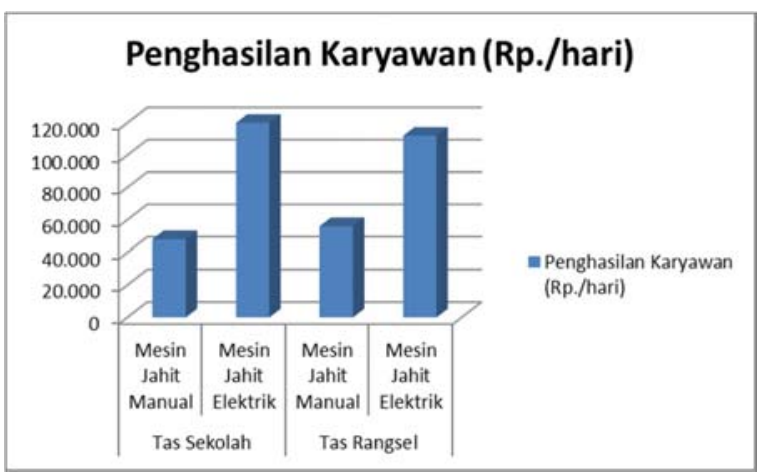

Gambar 2. Grafik Peningkatan Penghasilan Karyawan Produksi Tas Sekolah dan Tas Rangsel antara yang Dikerjakan dengan Mesin Jahit Manual dan Mesin Jahit Elektrik

Sebagaimana diketahui, bahwa UKM pengrajin tas yang menjadi mitra kerjasama dalam kegiatan program IbM ini adalah UKM "TAS ENDXEN" dan UKM "TAS SYAFAAT". UKM mitra ini masih tergolong sebagai industri rumah tangga (home industry), dimana dari aspek manajemen usaha selama ini di UKM mitra belum melaksanakan manajemen usaha dengan baik, terutama manajemen keuangan dan sumber daya manusia. Melalui perbaikan, pembenahan dan penataan manajemen yang dilakukan melalui pelatihan dan pendampingan oleh tim pelaksana program IbM ini, tujuan yang ditargetkan telah tercapai dengan baik, yakni dilaksanakannya manajemen usaha yang baik dan lebih professional oleh pengusaha UKM mitra. Untuk manajemen keuangan UKM mitra telah melakukan pembukuan arus keuangan kegiatan usaha, telah dilakukan pemisahan antara uang yang digunakan untuk kegiatan usaha dengan uang yang digunakan untuk kebutuhan hidup keluarga setiap hari. Dengan dilakukan pembukuan keuangan usaha, pengusaha UKM tas mitra dapat mengetahui besarnya modal usaha dan keuntungan yang diperoleh. Sedangkan untuk manajemen SDM, setelah mengikuti pelatihan dan pendampingan, hal-hal yang mengalami perubahan yang lebih baik adalah: a) daftar hadir karyawan mulai tersedia, b) disiplin waktu kerja karyawan mulai ditegakkan, c) pembinaan untuk meningkatkan kinerja karyawan telah dilakukan sekalipun tidak dilakukan secara periodic atau sifatnya insedentil. Dengan telah dilakukannya manajemen usaha yang lebih baik oleh pengusaha UKM mitra, maka upaya pengusaha untuk memajukan dan mengembangkan usahanya secara bertahap akan berhasil dan sukses dengan baik. Dengan demikian upaya peningkatan kualitas dan kuantitas produksi dan pengembangan manajemen UKM pengrajin tas mitra secara bertahap dapat terwujud.

\section{KESIMPULAN}

Dalam penerapan teknologi tepat guna (TTG) untuk meningkatkan kualitas dan kuantitas produksi UKM tas, telah diserahkan 4 unit mesin jahit elektrik, dengan rincian 2 unit mesin jahit elektrik diberikan kepada Hasanudin pengrajin "TAS ENDXEN" dan 2 unit mesin jahit elektrik lainnya diberikan kepada Muhammad Toyib pengrajin "TAS SYAFA'AT". Pengusaha dan karyawan UKM tas mitra telah mengikuti pelatihan dan pendampigan mengoperasikan mesin jahit elektrik dan mesin jahit elektrik sudah digunakan untuk kegiatan produksi. Dengan diterapkannya mesin jahit elektrik pada kelompok UKM pengrajin tas ini, pengusaha kecil pengrajin tas ini telah dapat meningkatkan produktivitas produksinya dan karyawan meningkat penghasilannya, yakni untuk jenis tas rangsel laptop menghasilkan tas laptop dari 7 tas/hari menjadi 14 tas/hari sehingga ada peningkatan produksi $100 \%$ dan upah untuk satu tas rangsel Rp. 8.000,- penghasilan karyawan meningkat dari Rp.56.000,00 menjadi Rp. 112.000,00, dan untuk jenis tas sekolah dari 12 tas/hari menjadi 30 tas/hari, sehingga ada peningkatan produksi $150 \%$ dan upah untuk satu tas sekolah Rp. $4000,-$, sehingga penghasilanya karyawan meningkat dari Rp. 48.000,00 menjadi Rp.120.000,00.

\section{REFERENSI}

[1] Kemendikbud. (2013). Panduan Pelaksanaan Penelitian dan Pengabdian kepada Masyarakat di Perguruan Tinggi Edisi IX. Direktorat Penelitian dan Pengabdian kepada Masyarakat. Direktorat Jenderal Pendidikan Tinggi. Jakarta: Ditjen Dikti.

[2] Maslov, D., Danilevsky and Sasav, V. (tanpa tahun). Engineering Manufacturing Processes. Peace Publishers Moscows.

[3] Niken, dkk. (1996). Pengaruh kemasan terhadap pemasaran suatu produk. Artikel yang dimuat di Majalah Forum Komunikasi FPTK se-Indonesia. IKIP Padang.

[4] Kementerian Negara Koperasi dan Usaha Kecil dan Menengah, (2007), Revitalisasi Koperasi dan UKM Sebagai Solusi Mengatasi Pengangguran dan Kemiskinan, Jakarta.

[5] Sujono,Sugondo. (1987). Teknologi Mekanik 2. Jakarta:Depdikbud DIKMenjur.

[6] Stefford, John dan Guy Mc. Murdo. (1983). Teknologi Kerja Logam. Diterj. Abdul Rahman. Jakarta: Erlangga. 
[7] Tjandra Wirawan, Ece Sudirman.(1992). Petunjuk kerja pelat dan tempa. Cet. 1. Jakarta: Depdikbud. Wiryosumarto, Harsono.(1999).

Teknologi Pengelasan Logam. Jakarta: Pradnya Paramita. 